\title{
Active Switched Capacitor Network in High Gain DC-DC Converter with PI Controller
}

\author{
Sowmya D, Dhanalakshmi R
}

\begin{abstract}
In this paper, PI controller in the active switched capacitor network is employed to achieve robust control under disturbance by maintaining sustained output voltage for varying input voltage. Active switched capacitor in the high gain DC-DC circuit efficiently increases voltage gain due to the combination of LC network with minimum duty cycle. The proposed circuit is the modification of typical high gain DC converter and modified network is simple in structure due to reduce in number of switch components and the voltage stress on the capacitor, diodes and across switches are reduced compared to base network. This paper presents the design, operation and analysis of the modified topology and the performance comparison with base converter is presented. Simulation is carried out using MATLAB software for the proposed system with and without PI controller and variation in the output voltage between both the circuits is tabulated and comparative analysis is discussed.
\end{abstract}

Keywords: High gain DC-DC network, active switched capacitor network, voltage gain, voltage stress, PI control.

\section{INTRODUCTION}

\section{A DC converter with high voltage are normally used}

power converters for Photo voltaic applications and they are used in dc power generators to meet load requirements. These converters are high in demand as they are used in many applications like in some medical equipment, electric tractions, automobiles, uninterrupted power supplies and mainly used in renewable energy conversion. A typical DC-DC boost converter was preferred to increase the voltage but the obtained voltage is not high enough. so, it cannot be applicable for high step up applications and also it requires higher operating duty cycle. Hence, voltage can be stepped up by using transformer less converters with minimum duty ratio and also the stress across power devices are minimized [1]. A bidirectional converter is simple in structure and it consists of coupled inductors which produces step up and step-down voltage higher than traditional converters [2] but the voltage stress across devices are high which leads to problems in reverse recovery. A novel converter can increase

Revised Manuscript Received on June 15, 2020.

* Correspondence Author

Sowmya D*, 2nd year PG student, power Electronics, Dayananda Sagar college of Engineering, Bangalore, India. Email: sowmya2795@gmail.com.

Dr. Dhanalakshmi R, Professor, Electrical and electronic department,

Dayananda Sagar, college of Engineering, Bangalore, India. Email: Dhanalakshmi-eee@dayanandasagar.edu

(c) The Authors. Published by Blue Eyes Intelligence Engineering and Sciences Publication (BEIESP). This is an open access article under the CC BY-NC-ND license (http://creativecommons.org/licenses/by-nc-nd/4.0/) voltage by implementing an inductor and voltage multiplier cells [3].

An interleaved Coupled-inductor converter [4] can acquire high output voltage without maximum duty ratio and voltage spikes can be reduced by adopting the active-clamp circuit [5]. voltage gain can be further amplified by increasing the number of turns in an inductor but this leads to occurring of current ripple. But the main constraint of this type of converter is transformer saturation. Hence, non-isolated converters can be used to attain higher voltage, where the isolation of circuits is not required. Integrating non-isolated converters with coupled inductor steps up voltage and reduces current ripple [6]. Further voltage can be increased by integrating an inductor and capacitor into same converter [7]. The current fed Cockcroft-Walton Multiplier in converter [8] act as a boosting system to produce desired output and eliminates occurring of voltage ripple and improves voltage gain and efficiency. Connecting a series of voltage-lift type inductors in a converter enhances voltage [9] and also by extending the active-passive inductor cells (APICs) [10] we can get much higher voltage with low voltage stresses on power devices but components used are high. Increasing number of levels in the converter [11] can step up the voltage with lower duty cycle but voltage stress will be very high and efficiency degrades due to hard switching. By employing soft switching techniques [12] like ZVS or ZCS increases efficiency but voltage stress across power devices will be high. Multilevel inverter employing PI controller for grid connected PV system [13] produces sinusoidal output current, unity power factor is maintained and for randomly changing atmospheric conditions high dynamic performance is obtained. Boost converter with cascade control loop [14] improves converter performance and by adding PI controller in the loop desired output is constantly maintained for varying input and also it eliminates disturbances occurring at load. In this paper, a basic high gain converter is modified by employing an active switched capacitor to overcome the drawbacks mentioned above and to mitigate the drawbacks of base converter shown in figure 1, such as number of switch components are less, low duty cycle used and voltage stress across switches are less compare to base converter. The voltage gain is increased by using only one with less duty ratio instead of using two different duty ratios. A PI controller is added in the converter to achieve robust control under varying input and disturbance. The design of the circuit, analysis and operating principle of the modified system is discussed in detail and also comparative analysis with base converter is also discussed.

Blue Eyes Intelligence Engineering 


\section{Active Switched Capacitor Network in High Gain DC-DC Converter with PI Controller}

\section{PROPOSED TOPOLOGY}

The topology as shown in the figure 2 is the modification of traditional non-isolated high gain converter which is shown in fig 1.

The modified topology includes one extra capacitor, diode is replaced between capacitor and switch $S_{1}$, and switch $S_{3}$ is removed. The converter is analyzed by assuming all the components are ideal and high capacitor values are considered to maintain constant voltage. The proposed topology consists of two modes of operation in CCM mode and it is explained below:

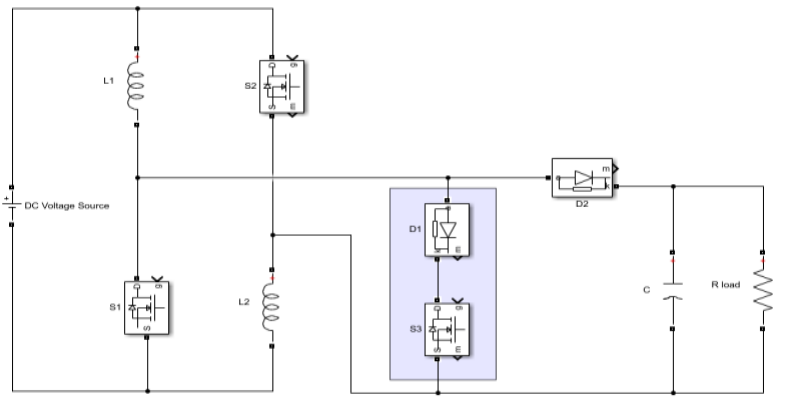

Fig.1 : base converter

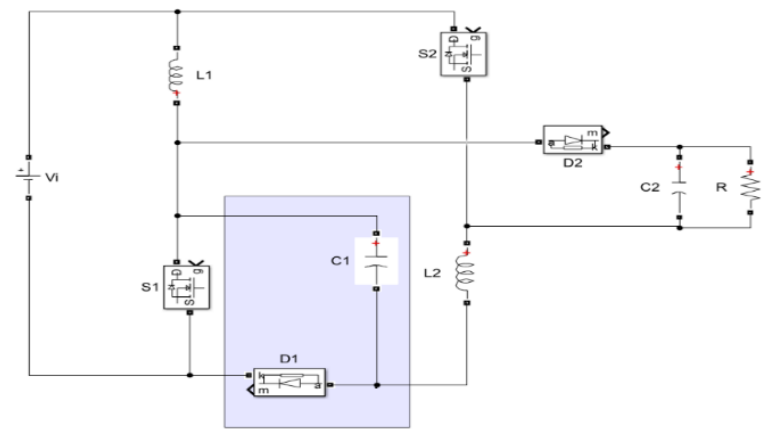

Fig.2 : proposed converter

Mode 1: Both the switches are in on condition and the diodes are not active. The inductors $L_{1}$ and $L_{2}$ are in charging mode and capacitor $\mathrm{C}_{1}$ and $\mathrm{C}_{2}$ are discharged towards inductor $\mathrm{L}_{2}$ and load, respectively. The voltages across inductors and capacitor currents are derived as

$V_{L 1}=L_{1} \frac{d i_{L 1}}{d t}=V_{i}$

$V_{L 2}=L_{2} \frac{d i_{L 2}}{d t}=V_{i}+V_{C 1}$

$i_{C 1}=C_{1} \frac{d v_{C 1}}{d t}=-i_{L 2}$

$i_{C 0}=C_{0} \frac{d v_{C 0}}{d t}=-I_{0}$

Mode 2: Here, Both the switches are in off condition and the diodes are turned on. The inductors discharges energy towards load due to their series connection with the input source and capacitor $C_{1}$ is in charging mode. The voltages and current equations are derived as

$V_{L 1}=L_{1} \frac{d i_{L 1}}{d t}=V_{i}-V_{C 1}$

$V_{L 2}=L_{2} \frac{d i_{L 2}}{d t}=V_{C 1}-V_{0}$

$i_{C 1}=C_{1} \frac{d v_{C 1}}{d t}=i_{L 1}-i_{L 2}$
$i_{C 0}=C_{0} \frac{d v_{C 0}}{d t}=i_{L 2}-I_{0}$

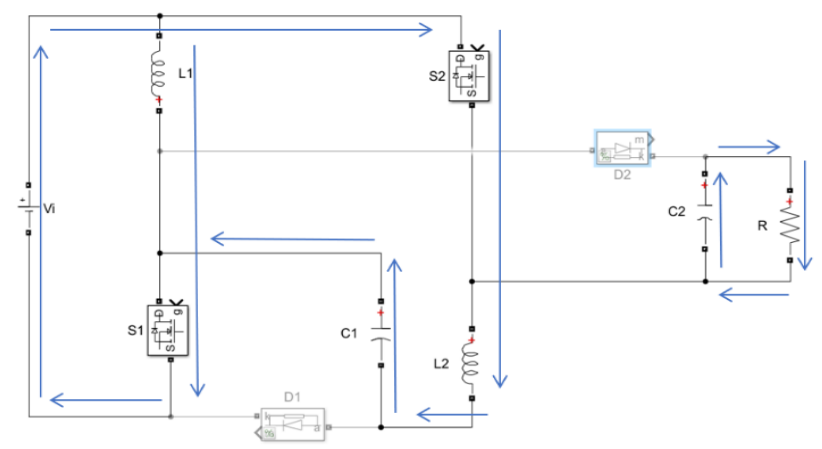

(a)

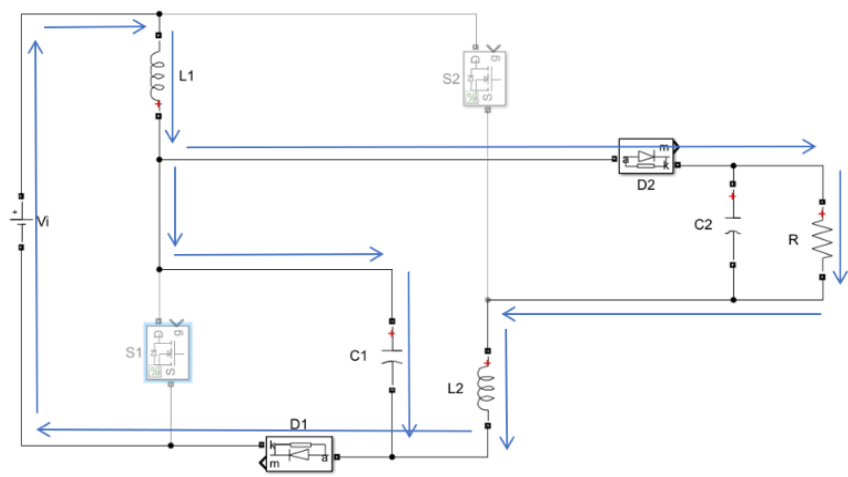

(b)

Fig. 3: CCM operation. (a) Mode 1. (b) Mode 2.

Voltage gain of the proposed topology is derived as:

$\int_{0}^{D T_{S}}\left(\frac{d_{i L 1}}{d t}\right)^{1} d t+\int_{0}^{(1-D) T_{S}}\left(\frac{d_{i L 1}}{d t}\right)^{2} d t=0$

$\int_{0}^{D T_{S}}\left(\frac{V_{i}}{L_{1}}\right) d t+\int_{0}^{(1-D) T_{S}}\left(\frac{V_{i}-V_{C 1}}{L_{1}}\right) d t=0$

$V_{C 1}=\frac{1}{1-D} V_{i}$

Similarly, apply volt-second balance principle for inductor $\mathrm{L}_{2}$,

$$
\begin{aligned}
& \int_{0}^{D T_{S}}\left(\frac{d i_{L 2}}{d t}\right)^{1} d t+\int_{0}^{(1-D) T_{S}}\left(\frac{d i_{L 2}}{d t}\right)^{2} d t=0 \\
& \int_{0}^{D T_{S}}\left(\frac{V_{i}+V_{C 1}}{L_{2}}\right) d t+\int_{0}^{(1-D) T_{S}}\left(\frac{V_{C 1}-V_{O}}{L_{2}}\right) d t=0 \\
& V_{0}=\frac{D V_{i}+V_{C 1}}{1-D} \ldots \ldots \ldots \ldots \ldots \ldots \ldots \ldots \ldots \ldots \ldots \ldots \ldots \ldots
\end{aligned}
$$

Substituting (1) into (2),

$$
M_{\text {ideal }}=\frac{V_{0}}{V_{i}}=\frac{1+D-D^{2}}{(1-D)^{2}}
$$

Here we are using duty ratio as $\mathrm{D}=0.65$,

$$
\text { Voltage Gain }=\frac{\left(1+0.65-(0.65)^{2}\right)}{(1-0.65)^{2}}=10
$$




\section{DESIGN PARAMETERS OF PROPOSED CONVERTER:}

The converter is rated for $100 \mathrm{~W}$ and $200 \mathrm{~V}$. The input is taken as $20 \mathrm{~V}$. Thus, output resistance and output current are calculated as follows:

$\mathrm{I}_{\mathrm{O}}=\frac{P_{O}}{V_{O}}=\frac{100}{200}=0.5 \mathrm{~A}$

$\mathrm{R}_{\mathrm{O}}=\frac{V_{O}^{2}}{P_{O}}=\frac{200 * 200}{100}=400 \Omega$

\section{A. Inductor design:}

To calculate inductor value, inductor ripple current is calculated based on this formula,

$\Delta i_{L}=\left(20 \%\right.$ to $40 \%$ of $\left.I_{0}\right) * \frac{V_{o}}{V_{\text {in }}}$

$\Delta i_{L 1}=1.3$ and $\Delta i_{L 2}=1.25$,

$L_{1}=\frac{V_{i} \mathrm{D}}{\Delta i_{L 1} f_{S}}=\frac{20 * 0.65}{1.3 * 50 K}=200 \mu \mathrm{H}$

$L_{2}=\frac{V_{i}}{\Delta i_{L 2} f_{S}} \frac{D(2-D)}{(1-D)}=\frac{20 * 0.65 *(2-0.65)}{1.25 * 50 K *(1-0.65)}=800 \mu \mathrm{H}$

\section{B. Capacitor selection:}

The capacitor is derived by applying capacitor charge balance principle,

$\int_{0}^{D T_{S}}\left(\frac{d V_{C 1}}{d t}\right)^{1} d t+\int_{0}^{(1-D) T_{S}}\left(\frac{d V_{C 1}}{d t}\right)^{2} d t=0$

$i_{L 1}=\frac{I_{0}}{(1-D)^{2}}$

Similarly, $\int_{0}^{D T_{S}}\left(\frac{d V_{C 0}}{d t}\right)^{1} d t+\int_{0}^{(1-D) T_{S}}\left(\frac{d V_{C 0}}{d t}\right)^{2} d t=0$

$i_{L 2}=\frac{I_{0}}{(1-D)}$

Substitute (3) and (4) in capacitor current equations and by assuming $\Delta V_{C 0}$ as 0.065 and $\Delta V_{C 1}$ as 0.84 , capacitor value can be calculated as,

$C_{1}=\frac{D}{(1-D)} \frac{I_{0}}{\Delta V_{C 1} f_{S}}=\frac{0.65 * 0.5}{(1-0.65) * 0.84 * 50 k}=22 \mu f$

$C_{O}=D \frac{I_{O}}{\Delta V_{C 0} f_{S}}=\frac{0.65 * 0.5}{0.065 * 50 \mathrm{~K}}=100 \mu \mathrm{f}$

\section{PROPOSED CONVERTER WITH PI CONTROLLER:}

A proportional-integral (PI) controller is a feedback control loop which consists of two tuning parameters, $K_{P}$ and $K_{i}$ and by properly tuning these parameters diminishes steady state error. PI control is needed for non-integrating processes, it produces constant output for varying inputs and disturbances. Figure 4 presents the Simulink model of the modified network with PI controller. The operation of controller in feedback takes place by first subtracting the output voltage of the circuit with the constant value and the error value obtained is feedback as an input to the controller. The control signal attained from the controller block is given as the input to the relational operator where it is compared with the triangular waveform and the generated pulses from the relational operator are given to the switches along with the appropriate delay.

The controller equation for PIC is as follows:

$$
\mathrm{U}(\mathrm{s})=\mathrm{K}_{\mathrm{p}} * \mathrm{E}(\mathrm{s})+\mathrm{K}_{\mathrm{i}} * \int \mathrm{E}(\mathrm{s})
$$

Where, $\mathrm{U}(\mathrm{s})$ is the controller output.

$\mathrm{E}(\mathrm{s})$ is the error signal obtained from the difference of constant value and converter output.

$\mathrm{K}_{\mathrm{P}}$ and $\mathrm{K}_{\mathrm{i}}$ are proportional and integral constants.

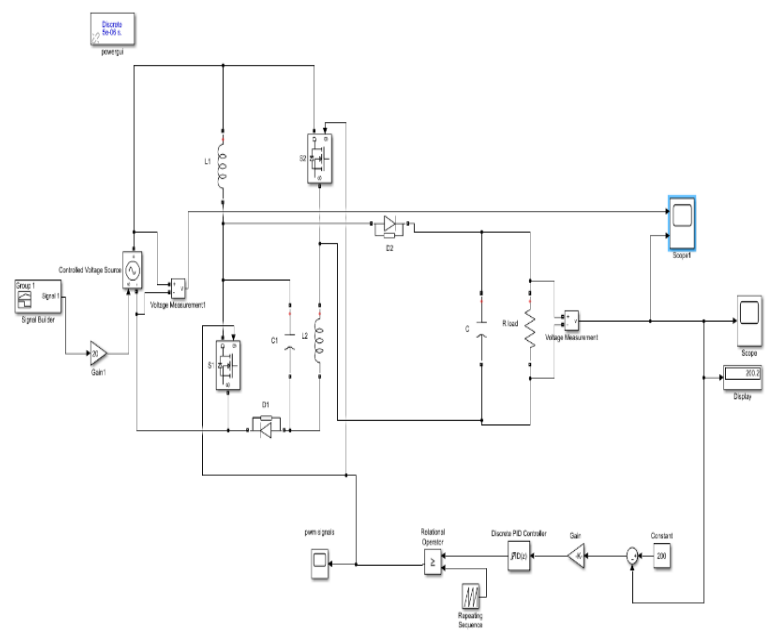

Fig 4: Simulink model of proposed topology

\begin{tabular}{|c|c|}
\hline \multicolumn{2}{|c|}{ Table I: Simulation parameters } \\
\hline Parameters & Value \\
\hline Input voltage & $20 \mathrm{~V}$ \\
\hline Output voltage & $200 \mathrm{~V}$ \\
\hline Rated power $\left(\mathrm{P}_{0}\right)$ & $100 \mathrm{~W}$ \\
\hline Switching frequency & $50 \mathrm{kHz}$ \\
\hline Duty ratio (D) & 0.65 \\
\hline Inductor $\left(\mathrm{L}_{1}, \mathrm{~L}_{2}\right)$ & $200 \mu \mathrm{h}, 800 \mu \mathrm{h}$ \\
\hline Capacitor $\left(\mathrm{C}_{1}, \mathrm{C}_{2}\right)$ & $22 \mu \mathrm{f}, 100 \mu \mathrm{f}$ \\
\hline Resistor $\left(\mathrm{R}_{\mathrm{O}}\right)$ & $400 \Omega$ \\
\hline
\end{tabular}

\section{SIMULATION RESULTS:}

Simulation is carried out based on the designed parameters given in Table I using MATLAB Simulink. The Simulink model of the proposed circuit with controller is represented in fig. 4 and the simulated results with and without controller are shown below.

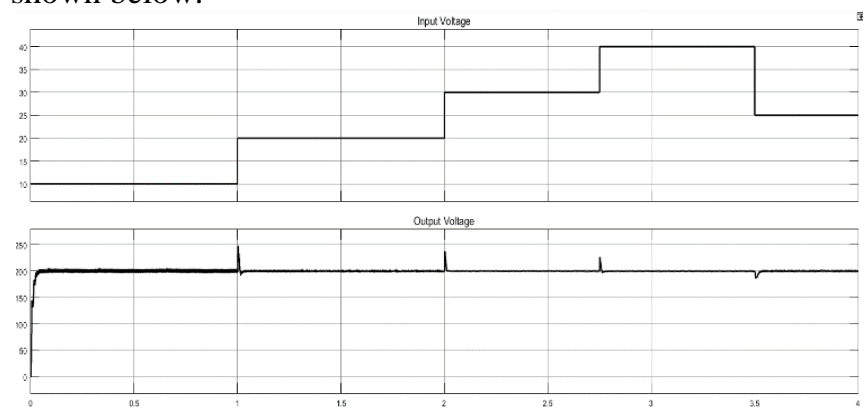

Fig 5 (a) : varying input and constant output voltage of converter with controller

Published By:

Blue Eyes Intelligence Engineering

\& Sciences Publication

(C) Copvriaht: All riahts reserved.

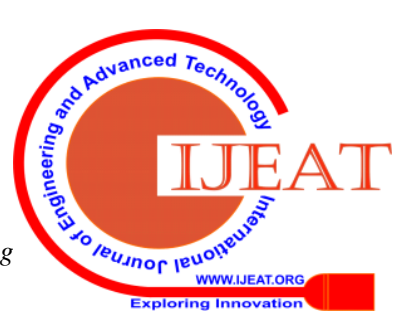




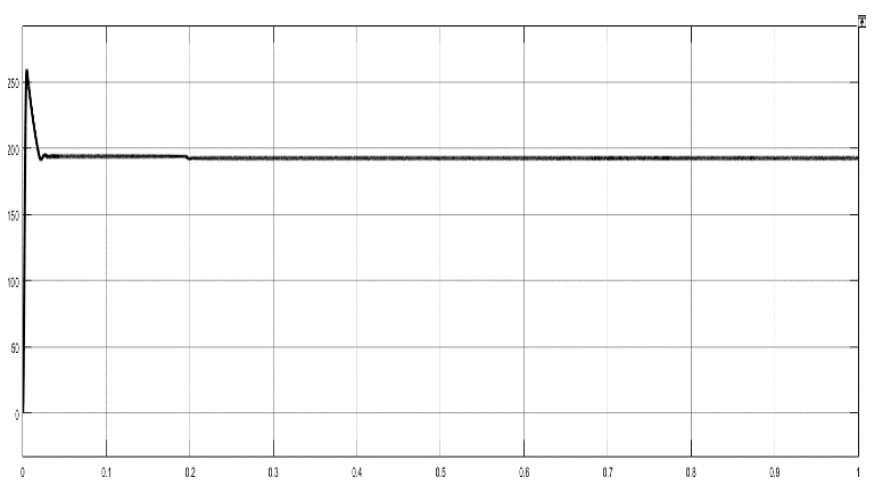

Fig 5 (b): converter output voltage without controller
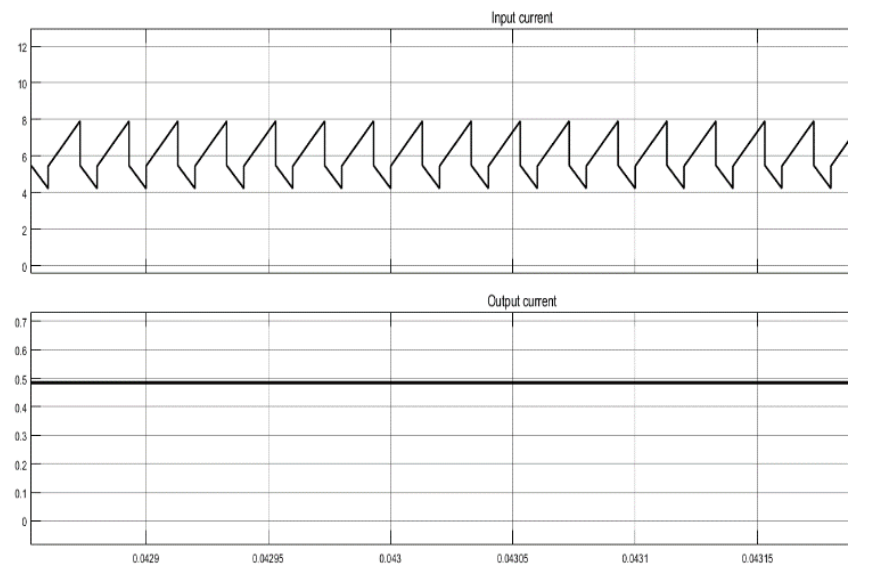

Fig 5 (c): input and output currents

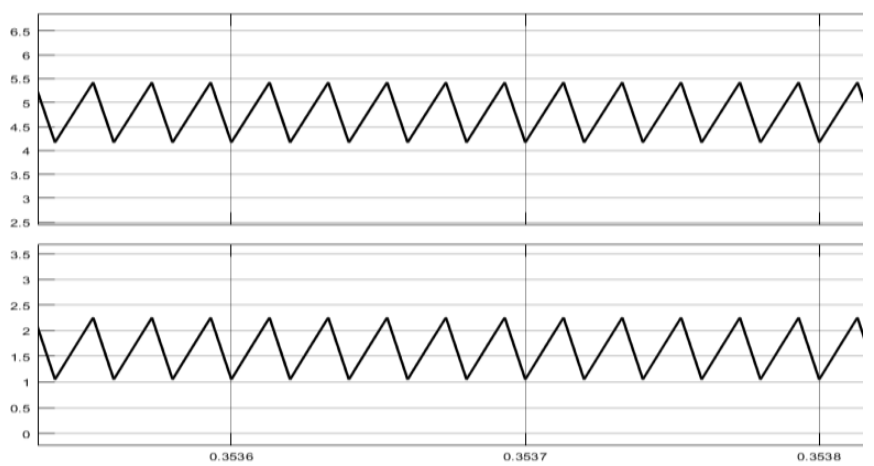

Fig 5 (d): inductor currents $\left(\mathbf{i}_{11}, \mathbf{i}_{12}\right)$

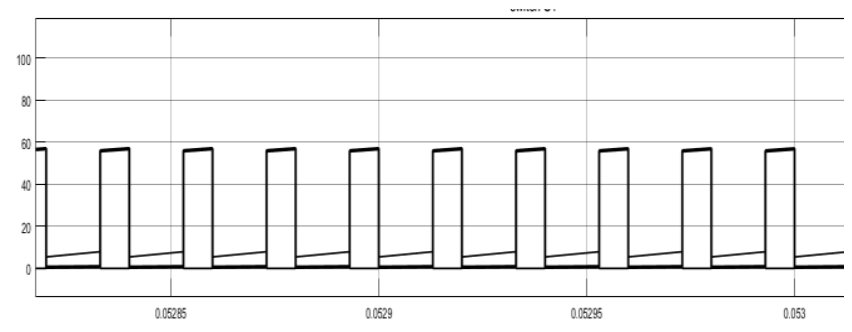

Fig 5(e): Switch $S_{1}$ voltage

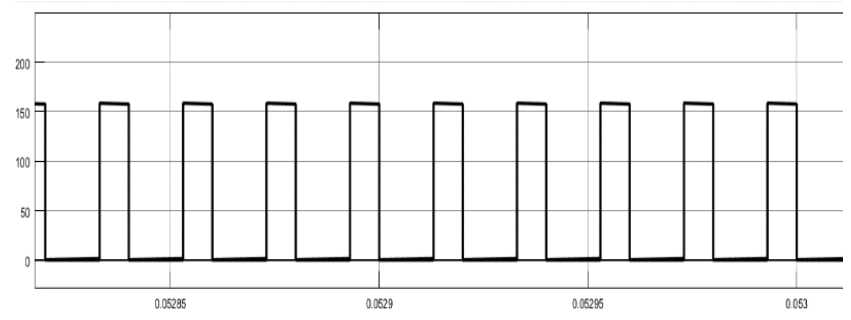

Fig 5 (f): Switch $S_{2}$ voltage

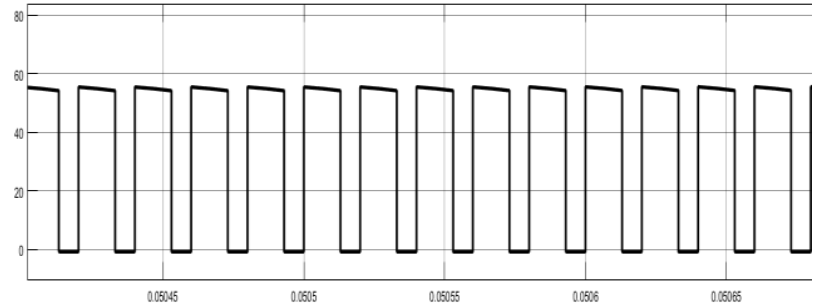

Fig 5(g): Diode $\mathrm{D}_{1}$ voltage

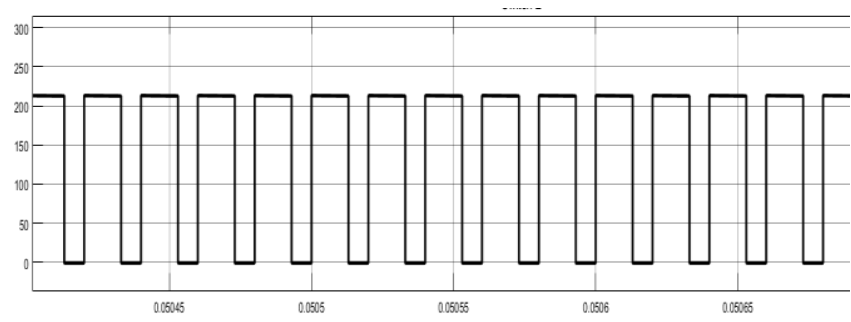

Fig 5 (h): Diode $\mathbf{D}_{2}$ voltage.

Figure 5 presents the simulation waveforms of the proposed circuit. Fig 5(a) shows the constant output voltage of the circuit with PI controller for alternative input voltages. Fig. 5(b) shows the output voltage of $193 \mathrm{~V}$ for input voltage of 20 volts and it is closed to the theoretically calculated value 200 $\mathrm{V}$ and a voltage gain of 9.65 is observed. This comparison of output voltage between two circuits is shown in Table II for different input voltages. Fig. 5(c) displays the input and output current waveforms with the mean value of the input current $=5.8 \mathrm{~A}$ and the output current $=0.48 \mathrm{~A}$ which are close to theoretical values. Fig 5(d) shows the inductor currents $i_{L 1}$ and $i_{L 2}$ where maximum and minimum currents are $\mathrm{i}_{\mathrm{L} 1(\max )}=5.4 \mathrm{~A}, \mathrm{i}_{\mathrm{L} 1(\min )}=4.16 \mathrm{~A}$ and $\mathrm{i}_{\mathrm{L} 2(\max )}=2.25 \mathrm{~A}, \mathrm{i}_{\mathrm{L} 2}$ (min) $=1.05 \mathrm{~A}$. Hence, change in inductor current is $\Delta i_{L}=1.2$ A. Fig. 5(e) and fig. 5(f) represents the Voltage stress on switches, $\mathrm{S}_{1}=56 \mathrm{~V}$ and $\mathrm{S}_{2}=157 \mathrm{~V}$ respectively. Fig. 5(g) and fig. 5 (h) shows voltage across diodes $V_{D 1}$ is $55 \mathrm{~V}$ and $V_{\mathrm{D} 2}$ is $211 \mathrm{~V}$ respectively, which are close to theoretical values.

\section{Table II: Comparison of output for different input} voltage.

\begin{tabular}{|c|c|c|}
\hline \multirow{2}{*}{$\begin{array}{c}\text { Input voltage } \\
\text { (Volts) }\end{array}$} & Output Voltage (Volts) \\
\cline { 2 - 3 } & Without PI controller & With PI controller \\
\hline $\mathbf{1 0}$ & 95 & 200 \\
\hline $\mathbf{2 0}$ & 193 & 200 \\
\hline $\mathbf{2 5}$ & 241 & 200 \\
\hline $\mathbf{3 0}$ & 292 & 200 \\
\hline $\mathbf{3 5}$ & 340 & 200 \\
\hline $\mathbf{4 0}$ & 388 & 200 \\
\hline
\end{tabular}

The table II shows the comparison of the circuit with and without PI control. From the above results we can conclude that the preformance of the modified converter with controller achieves robust control on output voltage for varying inputs. The table III displays the comparative analysis of the proposed with base circuit. The high gain of the base topology is attained at maximum duty cycle, but the proposed converter achieved at lower duty cycle only and this comparative analysis of the is shown in fig. 6 .

Published By:

Blue Eyes Intelligence Engineering

\& Sciences Publication

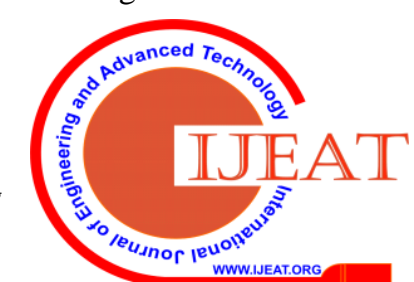


Also, the stress on switches of proposed are comparatively less the base converter and this is represented in fig.7. And the proposed system is operated with two switches only.

Table III : Comparison of proposed with base circuit:

\begin{tabular}{|l|l|l|}
\hline & \multicolumn{1}{|c|}{ Base topology } & Proposed topology \\
\hline Voltage Gain & $\frac{V_{O}}{V_{i}}=\frac{1+D_{1}}{1-D_{1}-D_{2}}=10$ & $\begin{array}{l}\frac{V_{0}}{V_{i}}=\frac{1+D-D^{2}}{(1-D)^{2}} \\
=10\end{array}$ \\
\hline Duty Cycle & $\begin{array}{l}\mathrm{D}_{1}=0.5 \\
\mathrm{D}_{2}=0.35\end{array}$ & $\begin{array}{l}\text { It requires lowest } \\
\text { duty cycle, } \mathrm{D}=0.65\end{array}$ \\
\hline $\begin{array}{l}\text { Voltage } \\
\text { stress on } \\
\text { Switches }\end{array}$ & $V_{D S 1,2}=\frac{V_{o}+V_{i}}{2}=110 \mathrm{~V}$ & $\begin{array}{l}V_{D S 1}=56 \mathrm{~V} \\
V_{D S 2}=157 \mathrm{~V} \text { which } \\
\text { is less than output } \\
\text { voltage. }\end{array}$ \\
\hline $\begin{array}{l}\text { Number of } \\
\text { Switches }\end{array}$ & $V_{D S 3}=V_{0}=200 \mathrm{~V}$ & \multicolumn{1}{c|}{2} \\
\hline
\end{tabular}

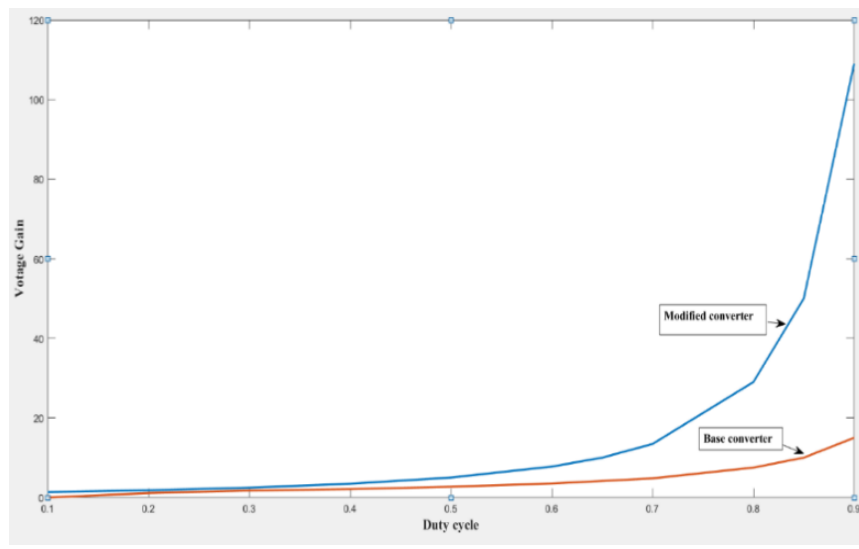

Fig.6: plot of voltage gain and duty cycle.

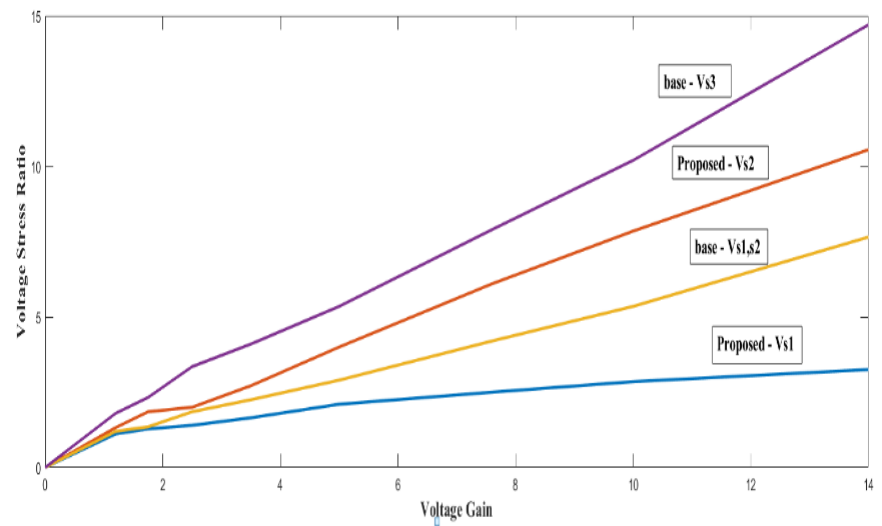

Fig.7: voltage stress versus voltage gain

\section{CONCLUSION}

The modified design, analysis and operation is discussed and the circuit is simulated using Simulink software to verify the circuit performance. The simulation results produce a voltage of $193 \mathrm{~V}$ for an input of $20 \mathrm{~V}$ and this proves that the high gain is achieved with minimum duty cycle of 0.65 . In addition, voltage stress across devices are reduced. The proposed topology is simulated with and without PI controller and comparative analysis is carried out and simulated results represent that the robust control is achieved for varying input voltage and disturbances.

\section{REFERENCES}

1. L. S. Yang, T. J. Liang, and J. F. Chen, "Transformer less DC-DC converters with high step-up voltage gain," IEEE Trans. Ind. Electron., vol. 56, no. 8, pp. 3144-3152, Aug. 2009.

2. L. S. Yang and T. J. Liang, "Analysis and implementation of a novel bidirectional DC-DC converter," IEEE Trans. Ind. Electron., vol. 59, no. 1, pp. 422-434, Jan. 2012.

3. H. C. Liu, F. Li, and J. Ai, "A novel high step-up dual switches converter with coupled inductor and voltage multiplier cell for a renewable energy system," IEEE Trans. Power Electron., vol. 31, DOI 10.1109/TPEL.2015.2478809, no. 7, pp. 4974-4983, Jul. 2016.

4. S. Dwari and L. Parsa, "An Efficient High-Step-Up Interleaved DC-DC Converter with a Common Active Clamp," IEEE Trans. Power Electron., vol. 26, no. 1, pp. 66-78, Jan. 2011.

5. T. F. Wu, Y. S. Lai, J. C. Hung, and Y. M. Chen, "Boost converter with coupled inductors and buck-boost type of active clamp," IEEE Trans. Ind. Electron., vol. 55, no. 1, pp. 154-162, Jan. 2008.

6. K. D. Kim, J. G. Kim, Y. C. Jung and C. Y. Won, "Improved non-isolated high voltage gain boost converter using coupled inductors," Int. Conf. Elect. Machines and Syst., Beijing, 2011, pp. 1-6.

7. Ajami, H. Ardi, and A. Farakhor, "A novel high step-up DC/DC converter based on integrating coupled inductor and switched capacitor techniques for renewable energy applications," IEEE Trans. Power Electron., vol. 30, no. 8, pp. 4255-4263, Aug. 2015.

8. A. Rajaei, R. Khazan, M. Mahmoodian, M. Mardaneh, and M Gitizadeh, "A Dual Inductor High Step-up DC/DC Converter Based on the Cockcroft-Walton Multiplier," IEEE Trans. Power Electron., vol. PP, DOI 10.1109/TPEL.2018.2792004, no. 99, pp. 1-1, Jan. 2018.

9. Y. Jiao, F. L. Luo, and B. K. Bose, "Voltage-lift split-inductor-type boost converters," IET Power Electron., vol. 4, DOI 10.1049/ietpel.2010.0093, no. 4, pp. 353-362, Apr. 2011.

10. H. M. Maheri, E. Babaei, M. Sabahi, and S. H. Hosseini, "High Step-Up DC-DC Converter with Minimum Output Voltage Ripple," IEEE Trans.Ind. Electron., vol. 64, DOI 10.1109/TIE.2017.2652395, no. 5, pp.3568-3575, May. 2017.

11. Girish Ganesan, R., \& Prabhakar, M. (2013). "Multi-level dc-dc converter for high gain applications". International Journal of Power Electronics and Drive Systems, 3(4), 365-373.

12. Milad Babalou, Morteza Dezhbord, Rasoul Shalchi Alishah and Seyed Hossein Hosseini "A Soft-Switched Ultra High Gain DC-DC Converter with Reduced Stress voltage on Semiconductors" 2019 10th International Power Electronics, Drive Systems and Technologies Conference (PEDSTC) 12-14 February, Shiraz University, Iran

13. J. Selvaraj, and N. A. Rahim, "Multilevel inverter for grid-connected PV system employing digital PI controller," IEEE Trans. Ind. Electron., vol. 56, no. 1, pp. 149-158, Jan. 2009.

14. Rabiaa, B.H. Mouna, S. Lassaad, F. Aymen, A. Aicha, "Cascade control loop of DC-DC Boost Converter using PI controller", 00978-1-5386-7328-7/18/\$31.00 (C2018 IEEE.

\section{AUTHORS PROFILE}

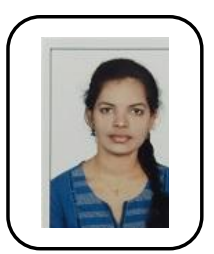

Sowmya D, pursuing $2^{\text {nd }}$ year $M$ tech, Power Electronics, Electrical and electronics department, Dayananda Sagar college of Engineering, Bangalore, India. Her interests are Power electronics, control system.

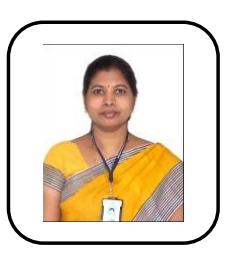

Dr. Dhanalakshmi.R, received Ph.D. from Anna University, Chennai, Tamil Nadu. She is working as a Professor in the Department of Electrical and Electronics Engineering, Dayananda Sagar College of Engineering, Bangalore. She has published a good number of research papers in reputed journals. Her research interest includes Renewable Energy conversion and control system, Power Electronics, Artificial Intelligent techniques and Optimization technique.

Published By:

Blue Eyes Intelligence Engineering \& Sciences Publication

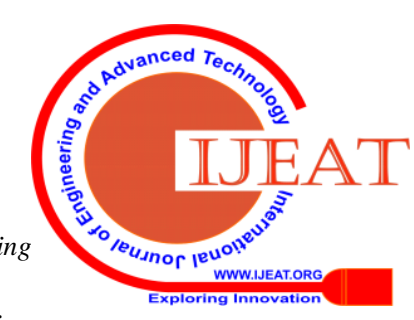

